\title{
ETHNO-CULTURAL COMPONENT OF BILINGUALISM IN THE CHECHEN REPUBLIC UNDER CONDITIONS OF REAL MONOETHNICITY
}

\author{
(C) Raisa S. Ilyasova \\ Chechen State University, Grozny, Russian Federation \\ science-almanac@mail.ru
}

Most sociolinguistic works devoted to the problem draw attention to the fact that the main factors affecting the language situation are the social conditions of language functioning. They determine both the level of development of the language and the prospects for its preservation and development. In this regard, the following points can be noted about the linguistic situation prevailing in the Chechen Republic, the level and quality of the Chechen-Russian bilingualism in the past and present. The Chechen language in the past, like many other Caucasian languages, was used verbally and existed in the form of living dialects. Religious, philosophical, fiction, scientific and educational literature was published in the Chechen language later. Works of oral folklore, annals, chronicles were recorded, clerical work, training, private correspondence, etc. were conducted. The research results show a clear dependence of the level of the Russian language proficiency on education, age and socio-demographic affiliation. Recently, for example, there has been a clear age tendency among Chechens to switch to Russian as a language of communication, which is precisely connected with the migration process, more precisely, with relocation to other Russian cities due to the war. It can be concluded that the third generation of Chechens who migrated to the Russian cities will be active bilinguals with a predominant knowledge of the Russian language: for example, if the first generation of migrants understands and speaks Chechen, then the second usually only understands, but does not speak (or speaks poorly), and accordingly their children, the third generation will neither understand nor speak Chechen, because people do not speak Chechen with them. The Russian language as a means of interethnic communication is an objective phenomenon. But it should not be accompanied by the displacement of native languages from the sphere of use by the narrowing of their functions and the inhibition of their structural development due to destructive nationallanguage policies. A reasonable, appropriate combination of bilingualism components is needed.

Key words: the Chechen language, native language, the Russian language, bilingualism, comparative description, sociolinguistics.

\section{[P.С. Ильясова Этнокультурная составляющая билингвизма в Чеченской республике в условиях реальной моноэтничности]}

В большинстве социолингвистических работ, посвященных рассматриваемой проблеме, обращено внимание на то, что основными факторами, влияющими на языковую ситуацию, являются социальные условия функционирования языка. Они определяют и уровень развития языка, и перспективы его сохранения и развития. В этом плане о сложившейся в Чеченской Республике языковой ситуации, уровне и качестве чеченско-русского двуязычия в прошлом и настоящем можно отметить следующие моменты. Чеченский язык в прошлом, как и многие другие кавказские языки, использовался в устной форме и существовал в виде живых наречий и говоров. Позднее на нем издавалась религиозная, философская, художественная, научная и учебная литература. Записывались произведения устного народного творчества, летописи, хроники, велось делопроизводство, обучение, частная переписка и др. Результаты исследований показывают четкую зависимость уровня владения русским языком от образования, возраста и социально-демографической принадлежности. В последнее время, например, среди чеченцев наблюдается явная возрастная тенденция к переходу на русский язык общения, которая совершенно точно связана с процессом миграции, точнее, с переездом в другие российские города в связи с войной. Можно заключить, что третье поколение мигрировавших в российские города чеченцев будет активными билингвами с преимущественным владением русским языком: так, если первое поколение мигрантов понимает и говорит по-чеченски, то второе - обычно только понимает, но не говорит (или плохо уже говорит), и соответственно их дети, третье поколение, поскольку с ними почеченски не разговаривают, уже не будут ни понимать, ни говорить по-чеченски. Русский язык как средство межнационального общения - объективное явление. Но оно не должно сопровождаться вытеснением родных языков из сферы употребления сужением их функций и торможением их структурного развития вследствие деструктивной национально-языковой политики. Необходимо разумное, целесообразное сочетание компонентов билингвизма. 
Ключевые слова: чеченский язык, родной язык, русский язык, билингвизм, сравнительносопоставительное описание, социолингвистика.

Raisa S. Ilyasova - Ph.D. in Philology, Associate Professor, Chechen State University, Grozny, Russian Federation.

Ильясова Раиса Сайтхасановна - кандидат фолологических наук, доцент, Чеченский государственный университет, г. Грозный, Российская Федерация.

At the present stage of development of social linguistics works of Avrorin V.A., Alpatov V.M., Baskakov A.N., Beloded I.K., Belousov V.N., Bertagaev T.A., Bliagoz Z.U., Desheriev Yu.D., Dzhunusov M.S., ZhuravlevaV.K., Isaev M.I., Krysin L.P., Kriuchkova T.B., Mikhailov M.M., Mikhalchenko V.Yu., Nikolskogo L.B., Protchenko I.F., Solntsev V.M., Tumanian E.G., Filin F.P., Khanazarov K.Kh., Shveitser A.D., Yudakin A.P., Iartseva V.N. and others are devoted to the problem of bilingualism and multilingualism as well as of diglossia.

The relevance of sociolinguistic studies of problems of national-language policy, language situation and bilingualism, is also determined by the fact that these problems have a direct connection with the problem of national relations, which is very relevant in the modern Russian Federation and in the whole post-Soviet space.

The particular relevance of the problems of the functioning of national languages, the language of inter-ethnic communication in a multinational State and the development of national-Russian bilingualism as a consequence of inter-ethnic and inter-linguistic processes is obvious and proved by practice (especially in modern times), along with clear shortcomings in addressing these issues, their coverage and justification during the Soviet period.

The social and linguistic analysis of development of the Chechen-Russian bilingualism which is closely coordinated by life to the main stages of implementation of national and language policy has to open and reveal many sides and features of bilingualism as a social and linguistic problem and to help to realize, comprehend and make possible attempts of overcoming consequences of those tragic events which were developed in the territory of the Chechen Republic within the last decade of the 20th century.

According to Khalidov A.I., "The main result of the post-Soviet period of the Chechen history in the sphere of national-language policy is a significant weakening of the influence of the Chechen literary language on the Chechen population: first, as a result of the reduction of many written spheres of its functioning in the press, in the publishing activity, in education, on television, as a result of the prevalence of simple and dialect language; secondly, as a result of migration of most of the Chechen population outside the Republic. The last factor, migration, has increased the influence of the Russian language greatly (most of the migrated population is in the "Russian-speaking" environment) and has encouraged the further development of bilingualism among this part of the Chechen people, which with long-term dispersed, non-compact residence in different parts of Russia outside the Republic can lead to the transition of migrants to the second language, Russian, and already leads to the transition of migrants in the "near abroad" from Chechen-Russian to "Russian-Chechen" bilingualism. Some of the settlers learn the state language in another relevant country (Ukrainian, Georgian, German, French, etc.), and this is inevitable, as communication with the indigenous population, occupation of some professional activity is impossible without it. As a result of the migration of a large part of the Chechen population outside the Republic, the social base of the Chechen literary language has been reduced" [6, p. 439].

Currently, the language situation in the Chechen Republic is slightly different than it was twenty or more years ago. On the one hand, the problem of "reverse" bilingualism is not so acute, on the other hand, the factor of the language environment, the presence in the 
republics of a large part of the Russian population, which had a certain influence on the activity of the rest of the population in the use of their native language, is slightly reduced. For example, in the Chechen Republic, the share of the Russian population has been decreased, tens of times, due to known events, the share of Russians in the neighboring Republic of Ingushetia is insignificant, and the structure of the population in other republics of the North Caucasus has changed significantly. In the changed environment, different approaches and principles are needed in the formulation and implementation of language policy and specific programs in the field of language life, designed both for the short-term future and for the longterm future. In particular, it is necessary to compensate for the decline of the factor of the language environment and to take measures to ensure that there will not be a sharp decrease in the level of knowledge of the Russian language in our republics.

The Chechen language, as is known, develops in close contact with the Russian language, and these ties have been continuing for hundreds of years and they have passed different periods.

"At the present time, we see such a close interaction between Chechen and Russian vocabulary in the nominative-functional sphere that it is not possible to at least approximately delimit assimilated Russian-language borrowing and Russian words fixed in the dictionary fund of the Chechen language, which are only occasionally used in the speech of the Chechen people and which are therefore outside the vocabulary-semantic system of the Chechen language. As is known, most Chechen people now speak both languages and are psychologically unable to assess Russian-language sneaking into the Chechen speech as something unusual, carrying national color and stylistically marked. In lexicology and stylistics, the term exoticism (referring to Russian words in Chechen texts) loses its meaning as a tool for the scientific description of language processes, as there is a blur of boundaries between lexical systems" [5, p. 396].

Sufficient attention has been paid to the comparative study of Chechen and Russian languages, to the theory and practice of teaching Russian in Chechen-speaking audiences. Until recently, priority was given to sociolinguistic aspects of the study of bilingualism, and the authors of the relevant works noted, first, the increasing role of Russian in the lives of modern Chechen people; secondly, that bilingualism is becoming a mass phenomenon in Chechnya; thirdly, the progressive influence of bilingualism on the Chechen language.

Maintaining our attitude towards the Russian language as the State language of the Russian Federation, the language of inter-ethnic communication, by means of which the entire population of the Russian Federation has access to full education, to all sources of all information, we should not forget that "the language within the ethnic boundaries of its speakers is not only and not so much a means of communication as the memory and history of the people, their culture and experience of cognitive activity, their worldview and psychology, their generation-to-generation baggage of knowledge about nature and space, about diseases and methods of their treatment, about education and preparation for life of new generations of people in the interests of preservation and multiplication of ethnos and its identity.

The preservation of any language, no matter how many people speak it, is necessary, because "any language is an expression of the uniqueness of each community, of a certain way in which they perceive and describe reality. Consequently, every language must be given all the necessary conditions to develop and fulfil its functions in all manifestations. Each language community has the right to create conditions and attract a variety of domestic means to guarantee the use of language in all social spheres."

The importance of issues of preservation and development of Russian and of all languages of the peoples of the Russian Federation, their importance for harmonization of inter-ethnic relations, ensuring civil unity, strengthening of state sovereignty and integrity of Russia was once again stated at the joint meeting of the Council on Inter-Ethnic Relations 
and the Council on the Russian Language on May 19, 2015. The decisions taken at this meeting should give a new impetus to complex, systematic work on preservation, study and support of languages of the peoples of Russia, giving hope for further development of multilingual educational and information space and allowing to coordinate efforts of state bodies, scientists-linguists and the whole society in this sphere.

The works of Ovhadov M.R. and Khalidov A.I. are devoted to the problems of the Chechen-Russian bilingualism [2], [3], [4], [6].

The Chechen language in the past, like many other Caucasian languages, was used verbally and existed in the form of living dialects. Religious, philosophical, fiction, scientific and educational literature was published in the Chechen language later. Works of oral folklore, annals, chronicles were recorded, clerical work, training, private correspondence, etc. were conducted.

Experts note that languages have equal legal rights but are not equal in functional terms. It is common knowledge that the sphere of functioning of the Russian language, which is more multi-functional, serving almost all areas of public life, increases every day. Accordingly, the degree of proficiency in Russian has been increasing. And the number of people who speak their native language has been decreasing.

Good knowledge of the Russian language usually does not lead to any change in the perception of the native language. National identity is a more sustainable national element than a national language.

The research results show a clear dependence of the level of the Russian language proficiency on education, age and socio-demographic affiliation. Recently, for example, there has been a clear age tendency among Chechens to switch to Russian as a language of communication, which is precisely connected with the migration process, more precisely, with relocation to other Russian cities due to the war. It can be concluded that the third generation of Chechens who migrated to the Russian cities will be active bilinguals with a predominant knowledge of the Russian language: for example, if the first generation of migrants understands and speaks Chechen, then the second usually only understands, but does not speak (or speaks poorly), and accordingly their children, the third generation will neither understand nor speak Chechen, because people do not speak Chechen with them.

The view of the positive influence of bilingualism on the ability to learn languages is based on the natural assumption that it is easier for a bilingual individual to learn the third language because he has more experience of learning languages in general than monolingual individuals. Beyond socio-psychological factors, this assumption itself is quite convincing. In general, it is more significant, probably, not the fact that the child had to master two languages from the earliest age, but the conditions under which this bilingualism arose and was realized [1].

Since early bilingualism occurs where there is a contact between two or more cultures, it is the complexity of the social environment as a whole that primarily affects the formation of the individual living in these conditions. Bilingualism is therefore not essential as such, but as one of the components of cultural complexity and at the same time the most explicit reflection of it. Bilingualism is observable, while the isolation of other factors from the totality of what forms the social environment is incomparably more complex [7, p. 65].

The study of bilingualism makes it possible to identify the applied aspects of the use of its results: the implementation of reasonable communication and language policy, taking into account the world information processes, the social organization of society at different levels of leadership and management, as well as the degree of learning of norms and values as the most important guidelines of human social activity.

The relevance of the study of bilingualism is also due to its general sociological lack of study. Modern bilingual processes have been developing very dynamically, and the study of 
bilingualism has not been sufficiently developed yet. There is practically no holistic social theory of this phenomenon.

As a highly complex, controversial process, bilingualism has attracted the attention of professionals in many countries around the world. However, there is currently no common understanding of the full range of issues covered by this problem.

The particular relevance of the problems of the functioning of national languages, the language of inter-ethnic communication in a multinational State and the development of national-Russian bilingualism as a consequence of inter-ethnic and inter-linguistic processes is obvious and proved by practice (especially in modern times), along with clear shortcomings in addressing these issues, their coverage and justification during the Soviet period.

The common place of all sociolinguistic works devoted to the problem under consideration is the indication that the main factors affecting the language situation are the social conditions of the functioning of the language. They determine both the level of development of the language and the prospects for its preservation and development.

\section{Лumepamypa}

1. Алпатов В.М. Языковая ситуация в регионах современной России. Отечественные записки. М., 2005. № 2(23).

2. Буралова Р.А., Халидов А.И. Тенденции чеченско-русского двуязычия и эколингвистическая ситуация в ЧР // Ж-л «Современные проблемы науки и образования». 2015. № 2-2. URL: http://science-education.ru/1929-21854. M., 2015.

3. Овхадов М.P. Социально-лингвистический анализ развития чеченско-русского двуязычия. Грозный, 2007. 204 с.

4. Овхадов M.P. Факторы развития чеченско-русского двуязычия // ж-л «Рефлексия». 2017. № 4. С. 38-41

5. Ильясова Р.С., Дадаева А.И. Об употреблении русизмов в чеченском языке. Горно-Алтайск, 2019. №6 (76). С. 396-397.

6. Халидов А.И. Языки и народы Кавказа: вопросы истории и типологии, социо-, этно- и эколингвистики. Махачкала: «Алеф», 2019. С. 439-446, 556-603.

7. 7. Хауген Э. Языковой контакт // Новое в лингвистике. Вып. 6, М.: Прогресс, 1972. C. $61-80$.

\section{References}

1. Alpatov V.M. lazykovaia situatsiia $\mathrm{v}$ regionakh sovremennoi Rossii. Otechestvennye zapiski. [Language situation in the regions of modern Russia. Domestic notes]. Moscow, 2005. No. 2(23) (in Russian).

2. Buralova R.A., Khalidov A.I. Tendentsii chechensko-russkogo dvuiazychiia i ekolingvisticheskaia situatsiia $v$ ChR. Zh-I "Sovremennye problemy nauki i obrazovaniia". [Trends of the Chechen-Russian bilingualism and ecolinguistic situation in the Chechen Republik. Journal "Modern problems of science and education."] 2015. No. 2-2. Available at: http://science-education.ru/1929-21854. Moscow, 2015 (in Russian).

3. Ovhadov M.R. Sotsialno-lingvisticheskii analiz razvitiia chechensko-russkogo dvuiazychiia. [Socio-linguistic analysis of the development of the Chechen-Russian bilingualism]. Grozny, 2007. 204 p. (in Russian).

4. Ovhadov M.R. Faktory razvitiia chechensko-russkogo dvuiazychiia. Zh-I "Refleksiia". [Factors of development of the Chechen-Russian bilingualism. Journal "Reflexia."] 2017. No. 4. pp. 38-41 (in Russian). 
5. Ilyasova R.S., Dudayeva A.I. Ob upotreblenii rusizmov v chechenskom iazyke. [On the use of borrowings from Russian in the Chechen language]. Gorno-Altaysk, 2019. No. 6 (76). pp. 396-397 (in Russian).

6. Khalidov A.l. lazyki i narody Kavkaza: voprosy istorii i tipologii, sotsio-, etno- i ekolingvistiki. [Languages and peoples of the Caucasus: issues of history and typology, socio-, ethno- and ecolinguistics]. Mahachkala: "Alef," 2019. pp. 439-446, 556-603 (in Russian).

7. Haugen E. lazykovoi kontakt. Novoe $v$ lingvistike. [Language Contact. New in Linguistics]. Issue. 6, Moscow: Progress, 1972. pp. 61-80 (in Russian). 